\title{
Article
}

\section{The Legal, Moral and Business Implications of Domestic Abuse and its Impact in the Workplace}

Bennett, Tony, Wibberley, Gemma and Jones, Carol

Available at http://clok.uclan.ac.uk/25828/

Bennett, Tony, Wibberley, Gemma ORCID: 0000-0002-7827-8227 and Jones, Carol (2019) The Legal, Moral and Business Implications of Domestic Abuse and its Impact in the Workplace. Industrial Law Journal, 48 (1). pp. 137-142. ISSN 0305-9332

It is advisable to refer to the publisher's version if you intend to cite from the work. http://dx.doi.org/10.1093/indlaw/dwy026

For more information about UCLan's research in this area go to http://www.uclan.ac.uk/researchgroups/ and search for <name of research Group>.

For information about Research generally at UCLan please go to http://www.uclan.ac.uk/research/

All outputs in CLoK are protected by Intellectual Property Rights law, including Copyright law. Copyright, IPR and Moral Rights for the works on this site are retained by the individual authors and/or other copyright owners. Terms and conditions for use of this material are defined in the policies page.

\section{CLoK}

Central Lancashire online Knowledge www.clok.uclan.ac.uk

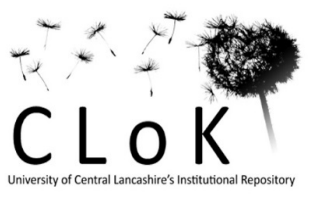


The legal, moral and business implications of domestic abuse and its impact in the workplace

\section{INTRODUCTION}

This article explores the impact of domestic violence in the workplace drawing on recently completed research ${ }^{1}$ that argued that, as highlighted in previous studies, the stigma surrounding domestic abuse continues to make it very difficult for employees to disclose their experiences ${ }^{2}$ resulting in disciplinary sanctions against many victims, as poor performance, attendance and other workplace problems are often misinterpreted. ${ }^{3}$ Crucially, in the unionised workplaces reported on in the research, there was however clear evidence (not previously identified) of partnership working between managers and union representatives that could positively address this devastating experience both for individuals and their organisations.

In the UK, domestic violence is defined as:

Any incident or pattern of incidents of controlling, coercive, threatening behaviour, violence or abuse between those aged 16 or over who are or have been intimate partners or family members regardless of gender or sexuality. This can encompass but is not limited to the following types of abuse: psychological, physical, sexual, financial, emotional. $^{4}$

\footnotetext{
${ }^{1}$ Wibberley, G. , Jones, C., Bennett, T. and Hollinrake, A. (2016) 'Domestic Violence-a management challenge: how trade unions can help', in Overcoming Challenges to Gender Equality in the Workplace: Leadership and Innovation, (eds.) Flynn, P., Haynes, K., and Kilgour, M., Greenleaf Publishing: Sheffield, pp.124-138; Wibberley G, Bennett T, Jones C. and Hollinrake A. (2018) The role of trade unions in supporting victims of domestic violence in the workplace, Industrial Relations Journal . Vol 49, 1,Pp 69-85
}

2 EHRC (2013) Evaluating the Impact of Domestic Abuse Workplace Policies in Wales Equality and Human Rights Commission Wales

\footnotetext{
${ }^{3}$ Swanberg, J., Macke, C., and Logan, T.K. (2007) 'Working women making it work. Intimate partner violence, employment, and workplace support', Journal of Interpersonal Violence, 22. 3, 292-311; Faichnie, C. (2010), "Work was an Escape for Me" - The Impact of Domestic Abuse on Employment, The Views of Women supported by the Domestic Abuse: Women's Employment Support Project,(DAWES).
}

${ }^{4}$ Strickland, P. (2013) Domestic violence : Standard Note : SN/HA/6337, London House of Commons Library, Home Affairs Section. 
Significantly, in the context of the discussion that follows, further evidence of the study's timeliness is the current progression of the Domestic Abuse Bill through the UK Parliament. Following on from earlier legislation, ${ }^{5}$ the Bill seeks 'to prevent domestic abuse by challenging the acceptability of abuse and addressing the underlying attitudes and norms that perpetuate it' ${ }^{6}$ However, in the consultation exercise conducted prior to the Bill going to the committee stage, there was no specific reference to the workplace. ${ }^{7}$ In some ways this reflects many employers' perspectives that domestic violence remains a 'private' matter. ${ }^{8}$ In contrast, recent legislation in New Zealand and Australia has facilitated paid and unpaid leave rights respectively for employees who are victims of domestic abuse. ${ }^{9}$ Similarly, in the US, several states have legislated for employers to provide unpaid leave, support employees seeking restraining orders and state funded unemployment benefits if a victim is forced out of employment. 10

An extensive critical review of the extant literature conducted in the course of the research revealed that there were few if any studies in the UK on the impact of domestic violence in the workplace and on how those experiencing it and their employers dealt with the issues that arose.

Working closely with the TUC across the North of England, the study investigated how union representatives and officers, when presented with a member who is experiencing domestic violence, seek to address the issue. The first phase of the research was based on semi-structured interviews with 18 trade union officers and representatives. ${ }^{11}$ The second phase, based on

5 HM Government (2013) Clare's Law https://www.gov.uk/government/news/clares-law-to-become-a-national-scheme Accessed 171018

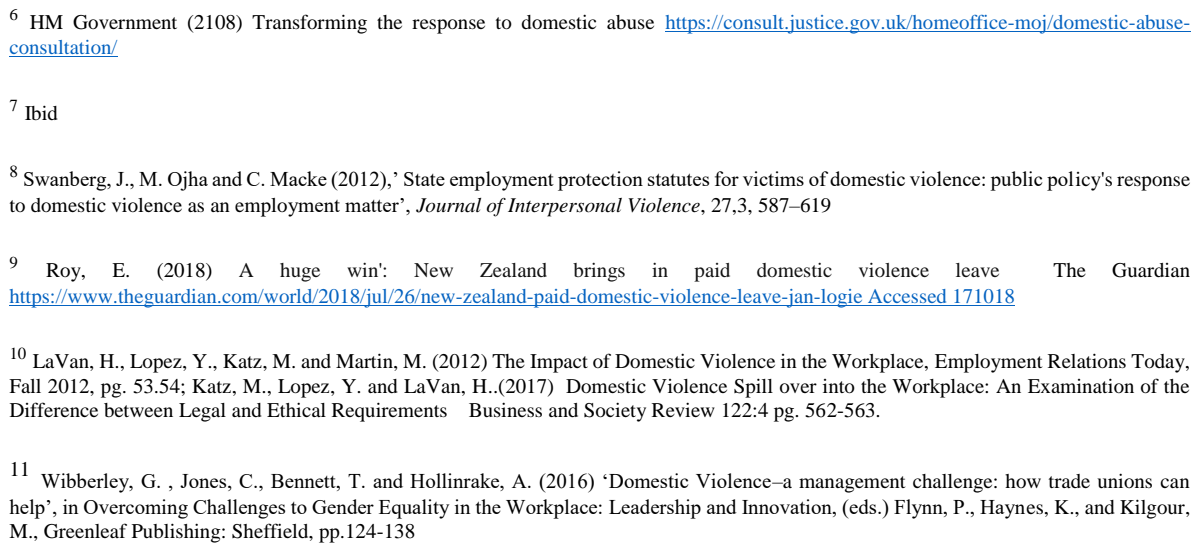

11 Wibberley, G. , Jones, C., Bennett, T. and Hollinrake, A. (2016) 'Domestic Violence-a management challenge: how trade unions can help', in Overcoming Challenges to Gender Equality in the Workplace: Leadership and Innovation, (eds.) Flynn, P., Haynes, K., and Kilgour, M., Greenleaf Publishing: Sheffield, pp.124-138 
similar qualitative research methods, sought the views and experiences of nearly 40 full-time union officers and lay representatives from across industrial sectors in the region. The focus of this article is primarily on the findings from the first tranche of the project. Early analysis of phase two data, however, corroborates the key themes and a detailed report of those findings will be available next year.

\section{THE MANIFESTATION OF DOMESTIC ABUSE ISSUES IN THE WORKPLACE AND ADDRESSING ITS IMPACT}

A significant finding from the research is that disclosure of abuse tends only to happen when the employee is faced with serious discipline or absence sanctions. Best practice in these situations saw union representatives and line managers, with the support of HR colleagues, recognising the real reason for these performance issues and then working together to agree appropriate adjustments to support the employee to remain and perform effectively in her/his job. This could involve a change of work location, a change in work patterns, more understanding and support if the abuse meant that the victim on occasion was prevented from getting to the workplace and ensuring that the perpetrator did not victimise the employee whilst in the workplace. Interviewees explained that, unless the matter is treated in this way, an employee, faced with questions from HR or managers is very unlikely to tell them that they are experiencing domestic violence. The research suggests that it is necessary, therefore, for organisations to better understand the root causes of an employee's behaviour if they are to develop effective approaches to support them. As one officer noted:

'They feel weak because they can't cope with it. And I think mostly it's not understood either. I think the fear is that people feel that they think someone sees less of them as a person because they are putting up with it. And you know, I think, there's a fear actually of leaving. How will I do on my own? How will I manage if there are kids? How will I have money? All those sort of things; I think that's why people don't disclose so easily. And I think it is only when a crisis occurs or they've been badly beaten, you know, and suffered a lot ${ }^{\text {. }}$

The research argues that trust is therefore vital. Nevertheless, as one typical account illustrates, it often remains difficult to persuade an employee even to tell their union representative until circumstances give them no option: 
"'I'm at the hospital", she said "I don't want to go into why...but I don't know what to do. I know that if I have another absence I'll go to a stage three which is at risk of dismissal", she said "but I can't come into work today".

\section{TRAINING AND AWARENESS RAISING}

Another key finding was the value of raising awareness amongst both trade unions and line managers of the effect that domestic violence can have and of being more aware of how to deal with the consequences when they arise. For instance, the knowledge of to whom to signpost a victim for more specialised help was crucial for all interviewees. Respondents also highlighted that most managers 'don't know how to deal with the situation because they're not trained'. Similarly, that many managers were unlikely to consider domestic violence as a reason behind an employee's attendance or performance issues and would expect an employee to be able to explain why they were taking time off work or arriving late. As one union officer recalled:

'She just suddenly would start crying and get upset about things... her manager thought it was a sort of training issue and that she didn't know how to handle stroppy customers......they sent her on all these tedious training courses...she was perfectly competent at her job. But she didn't want to say actually 'I'm not getting upset because someone's shouting at me. I'm getting upset because of what's happening outside of my work'.

The research noted that an excellent workplace-focussed example of sharing good practice was the Northumbria Police and Crime Commissioner office's 'Workplace Domestic Abuse Champions' initiative; where employees from across industries and organisations have undergone short training courses to enable them to raise awareness of its impact in their workplaces and to signpost colleagues who are experiencing abuse to sources of support. ${ }^{12}$

\section{THE IMPORTANCE OF COHERENT POLICIES AND PROCEDURES}

Performance issues, that have their roots in cases of abuse and the conflict this raises with respect to existing policies and procedures, were another key barrier for most of the representatives:

\footnotetext{
12 http://www.northumbria-pcc.gov.uk/police-crime-plan/domestic-and-sexual-abuse/ Accessed 171018
} 
'They come in late, they go home early, they are often sick ....but my experience is it's because there is no policy that allows people to be honest about the fact. People try and cage it in different ways that enables them to survive; it's a coping strategy'.

Many organisations now have absence and performance management policies. However, the research noted that there was often a strict focus on measuring staff absence and poor performance with line managers expected to resolve the reasons. This was not a role that most line managers relished or were well trained to undertake. Therefore, they may misinterpret patterns. For instance, staff not coming in on Mondays because they have been physically abused; or as in the case cited above, assuming a staff member needs training in how to handle difficult customers when they were actually trying to deal with domestic abuse whilst still holding down their job. As these accounts by reps further emphasise:

'She was really scared of losing her job...because it's the three strikes and you're out... And she had previous sicknesses [from the abuse].'

'When you ring up...to say that you're not coming in...they give you the third degree of why you're not coming in... It's tough enough that you have to go through things... It takes just so much courage to speak up but then you have to go through it with someone who you've never met....and you just don't feel comfortable doing so.'

Fundamentally, work is important to victims and not just financially. The research found that there was a fear that, if they disclose, they are perceived as weak or incompetent; and that disclosure would have negative consequences for their careers, particularly if the police or social services become involved. Furthermore, if a partner found out this could lead to an escalation of violence. Many victims were believed also to have a real concern over the reactions of co-workers. It is thus of little surprise that they might go to great lengths to conceal what was happening; and only disclosed if a crisis point had occurred - such as facing sanctions by their employer - and, even then, some would leave their employment rather than disclose. The research suggests that organisations need to review their policies to ensure that if they have a domestic abuse policy then other policies (such as absence or capability policy) acknowledge domestic abuse in these contexts as a possible reason for an employee's behaviour, thus preventing potential conflict between policy and practice from arising.

\section{CONCLUSION: INFLUENCING THE LAW?}

In July 2018 Dame Vera Baird, Police and Crime Commissioner for Northumbria, and the central instigator of the domestic violence champions' initiative cited above, was a keynote speaker for the conference to report back on the research to date. She advocated, to the delegates and speakers at the conference, the need to lobby the Government to specifically 
include in the Domestic Abuse Bill the workplace actions reviewed in the research and considered in this article.

At the time of writing, the Bill was at its committee stage. It is hoped that in the spirit, if not the letter, of the law that this counsel is heeded; none the least through the consultative process that look place earlier this year with a wide range of interested groups, including those from the trade union movement.

The research points to a clear moral, legal and business case for addressing the impact of domestic abuse in the workplace. ${ }^{13}$ Morally, employers have a duty of care to provide support and make reasonable adjustments to ensure that victims become survivors and the workplace is a haven and source of financial independence. As the research has further argued, this right to support should be enshrined in law. Finally, it has pointed to a clear business case that such actions would improve performance, lower absence and resignation rates and increase commitment from all staff.

\section{TONY BENNETT}

Sheffield Business School, Sheffield Hallam University

\section{GEMMA WIBBERLEY AND CAROL JONES}

Lancashire School of Business and Enterprise, UCLAN

Email: sbsab@exchange.shu.ac.uk

\footnotetext{
13 Dickens, L. (1999) Beyond the business case: a three-pronged approach to equality action Human Resource Management Journal Vol. 9 No. 1 .
} 